(C) С.Ф. Юхимчук, к.т.н., С.М. Юхимчук, М.М. Толстушко, к.т.н., Л.М. Дацюк, к.т.н.

Луцький національний технічний університет

\title{
ОБГРУНТУВАННЯ ПАРАМЕТРІВ БРАЛЬНОЇ ЛАНКИ ЛАНЦЮГОВОГО ЛЬОНОБРАЛЬНОГО АПАРАТУ
}

У статті дано опис конструкиії та принцуипу роботи принципово нового ланцюггового брального апарата, використання якого дозволить при збиранні льону усунути розтягнутість стебел у стрічці. А також, теоретично обтрунтовано основні параметри бральної ланки ланцюгового льонобрального апарату.

Постановка проблеми. До основних недоліків пасових апаратів відносяться розтягнутість стебел у стрічці, що формується, і обрив насіннєвих коробочок при розділенні стеблостою льону при 
підведенні стебел до бральних рівчаків. У статті подане вирішення цих проблем на основі запропонування нової конструкції брального апарату 3 обгрунтуванням його параметрів, необхідних для його проектування.

Аналіз останніх досліджень і публікацій. В існуючих пасових льонобральних апаратах стеблостій льону спрямовується до бральних рівчаків подільниками, які розділяють стеблостій i формують так звані пучки стебел. У результаті бокові стебла пучка нахиляються боковими прутками подільників, а центральні - ні. Виникає таке небажане явище як розтягнутість стебел у стрічці, що формується, - тобто стебла у стрічці зміщені одні відносно інших. А це в свою чергу збільшує ширину стрічки. Крім того при розділенні стеблостою на пучки відбувається обрив насіннєвих коробочок, так як стебла льону сплетені між собою. Щоб зменшити вказані недоліки пропонуємо принципово нову конструкцію брального апарату - ланцюгового типу (рис.1) [1].

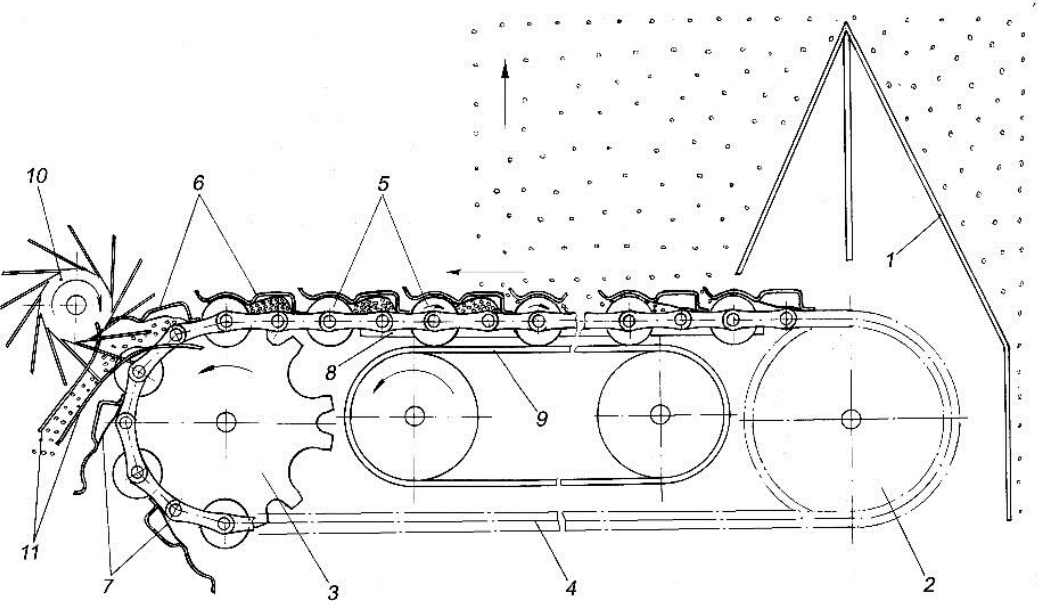

Рис.1 - Ланцюговий льонобральний апарат: 1 - польовий подільник; 2 ведена зірочка; 3 - ведуча зірочка; 4 - ланцюг; 5 - бральні ролики, 6 - бральні пластини;7 - гумові підтримувачі; 8 опорний транспортер; 9 - привідний пас; 10 - відкидна крильчатка; 11 - направляючі прутки

Ланцюговий льонобральний апарат складається із рами (на рисунку не показана), на якій встановлені польовий подільник 1 , бральний пристрій, що містить ланцюгову передачу, яка 
складається із веденої 2 та ведучої 3 зірочок, ланцюга 4. На ланцюзі 4 закріплені бральні ролики 5, бральні пластини 6 і гумові підтримувачі 7. Знизу під робочою віткою ланцюгової передачі встановлений опорний транспортер 8, виконаний у вигляді бігової доріжки За роликами розміщений привідний пас 9 , а над ведучою зірочкою 3 ланцюгової передачі - вивідний пристрій у вигляді відкидної крильчатки 10 і направляючих прутків 11.

Ланцюговий льонобральний апарат працює наступним чином.

Обертальний момент від приводу машини чи трактора (в залежності від типу машини, на якій встановлений льонобральний апарат) через механізм приводу передається до ланцюгової передачі, привідного паса 9 та відкидної крильчатки 10. При русі машини по полю польовий подільник 1 відділяє стеблостій льону і при переміщенні ланцюга 4 стебла льону потрапляють у бральні рівчаки, утворені загнутими частинами бральних пластин 6 та бральними роликами 5, де і затискаються. Бральні ролики 5, контактуючи із віткою привідного паса 9, обертаються i переміщують стебла, що підтримуються бральними пластинами 6. При цьому затиснені стебла витягуються 3 грунту i, при подальшому обертанні бральних роликів 5, потрапляють в простір за бральними роликами 5 , де утримуються гумовими підтримувачами 7 і так транспортуються. На виході з брального апарату за рахунок перегину ланцюга 4 на ведучій зірочці 3 бральні планки 6 відходять від бральних роликів 5, підштовхуються гумовими підтримувачами 7 та відкидною крильчаткою 10 , викидаються з брального апарату i, ковзаючи по направляючих прутках 11, розстеляються по полю. Щоб робоча вітка ланцюгової передачі не провисала при бранні льону, вона спирається на опорний транспортер 8, виконаний у вигляді бігової доріжки. Тиск у бральних рівчаках регулюється одночасно по всій ширині захвату агрегату за допомогою збільшення натягу ланцюга 4 переміщенням веденої зірочки 2. Внаслідок відсутності подільників, які в інших бральних апаратах розділяють і підводять стеблостій льону до кожного брального рівчака, зменшується розтягнутість стебел у стрічці та обрив насіннєвих коробочок. При роботі відбувається рівномірне забирання стебел, при цьому стебла, що затиснулись, i сусідні стебла, що тільки мають потрапити у бральний рівчак, знаходяться на віддалі на якій розрив зчеплених насіннєвих коробочок стебел не відбувається.

Використаний принцип брання стебел льону полягає у затисненні стебел між роликом, що обертається, чи пасом, що 
рухається, i нерухомою притискною пластиною чи прутками використовується і в інших конструкціях бральних апаратів [2], [3] та обгрунтований у праці [4].

Мета досліджень. Метою даної статті $\epsilon$ теоретичне обгрунтування основних параметрів ланцюгового льонобрального апарату, точніше бральної ланки, яке б підтвердило можливість подальшого проектування даної конструкції.

Для цього потрібно вирішити такі задачі: 1) підібрати швидкість руху ланцюга; 2) обгрунтувати крок розміщення бральних ланок на ланцюзі; 3) підібрати радіус ролика і кутову швидкість його обертання; 4) величину зони обхвату ролика притискною пластиною - зони затискання стебел у бральній ланці при бранні.

Результати дослідження. Для обгрунтування цих параметрів, як вихідні умови приймаємо, що ширина захвату брального апарату, по аналогії 3 існуючими, рівна $\mathrm{B}=1,5$ м; швидкість руху машини - 8 км/год, тобто $\mathrm{v}_{\mathrm{m}}=2,2 \mathrm{M} / \mathrm{c}$; густота стеблостою льону (приймаємо найбільш типове значення) $\mathrm{i}_{\mathrm{c}}=1800$ шт./м²; середній діаметр стебла $\mathrm{d}_{\mathrm{c}}=2 \mathrm{мм}$.

Швидкість руху ланцюга вибираємо з таких міркувань, щоб стебла, які підходять до бральних секцій, зразу ж забирались. Це необхідно, щоб не виникало накопичення стебел перед бральним апаратом. I при забиранні, тобто затисканні, бранні i транспортуванні, відстань між сусідніми стеблами не збільшувалась - щоб не було обриву насіннєвих коробочок у переплетених між собою стеблах. Це можна досягнути, коли швидкість їх забирання i швидкість підведення стебел однакові, тобто коли швидкість переміщення бральних ланок (швидкість ланцюга) буде рівна швидкості машини $\mathrm{v}_{\text {л }}=\mathrm{v}_{\mathrm{м}}=2,2 \mathrm{M} / \mathrm{c}$.

За таких умов, якщо крок між бральними секціями $\mathrm{t}$, то одна бральна секція забирає льон з площі рівній $\mathrm{S}=\mathrm{B} \cdot \mathrm{t}$. А знаючи густоту стеблостою, можна знайти скільки стебел буде утримуватись у бральній секції на виході 3 апарату: $\mathrm{i}_{\text {б.c }}=\mathrm{i}_{\mathrm{c}} \cdot \mathrm{S}=\mathrm{i}_{\mathrm{c}} \cdot \mathrm{B} \cdot \mathrm{t}$. Простір, який будуть займати ці стебла, за умови пошарового їх розміщення буде: $\mathrm{i}_{б . c} \cdot \mathrm{d}_{\mathrm{c}}^{2}$.

3 конструктивних міркувань приймаємо, що відстань між роликами рівна діаметру ролика, тоді крок $\mathrm{t}=4 \cdot \mathrm{R}$, де $\mathrm{R}$ - радіус ролика. Розмір утримуючої комірки, прив'язуючись до радіуса ролика, вибираємо $2 \mathrm{R} \cdot \mathrm{R}=2 \mathrm{R}^{2}$. В цій комірці повинні поміститися 


\section{Сільськогосподарські машини. Випуск 43}

усі стебла, вибрані однією бральною секцією, тобто $2 \mathrm{R}^{2}=\mathrm{i}_{\text {б.c }} \cdot \mathrm{d}_{\mathrm{c}}^{2}=\mathrm{i}_{\mathrm{c}} \cdot \mathrm{B} \cdot \mathrm{t} \cdot \mathrm{d}_{\mathrm{c}}^{2}$.

Розв'яжемо систему рівнянь:

$$
\left\{\begin{array}{l}
t=4 \cdot R \\
2 R^{2}=i_{c} \cdot B \cdot t \cdot d_{c}^{2}
\end{array}\right.
$$

при $\mathrm{i}_{\mathrm{c}}=1800$ шт $/ \mathrm{M}^{2}, \mathrm{~B}=1,5 \mathrm{~m}, \mathrm{~d}_{\mathrm{c}}=0,002$ м отримаємо, що $\mathrm{R}=21,5$ мм, $\mathrm{t}=86 \mathrm{Mm}$.

Для визначення колової швидкості ролика, вдамося до наступних міркувань. Час, за який певна точка ланцюга, що рухається з швидкістю $\mathrm{v}_{\text {л }}$, пройде відстань рівну ширині захвату $\mathrm{B}$ , становить $\tau=\mathrm{B} / \mathrm{v}_{\text {л }}$. За цей час стебла, що попадають у бральну секцію, за умови, що в зоні затискання між роликом і пластиною вони знаходяться одне біля одного, повинні пройти зону затискання i зібратися в утримуючій комірці: $\tau \geq \frac{\mathrm{i}_{\text {б.c }} \cdot \mathrm{d}_{\mathrm{c}}}{\mathrm{v}_{\mathrm{k}}}$. Тобто колова швидкість ролика вибирається з умови:

$$
\begin{aligned}
& \mathrm{v}_{\mathrm{p}}= \frac{\mathrm{i}_{б . c} \cdot \mathrm{d}_{\mathrm{c}} \cdot \mathrm{v}_{\text {л }}}{\mathrm{B}}=\mathrm{i}_{\mathrm{c}} \cdot \mathrm{t} \cdot \mathrm{d}_{\mathrm{c}} \cdot \mathrm{v}_{\text {л }}=1800 \cdot 0,086 \cdot 0,002 \cdot 2,2=0,68 \mathrm{M} / \mathrm{c} .(2) \\
& \text { Приймаємо } \mathrm{v}_{\mathrm{p}}=0,7 \mathrm{M} / \mathrm{c} .
\end{aligned}
$$

Визначимо необхідну величину зони затискання стебел у бральній секції при їх бранні. Для цього розглянемо схему на рис. 2.

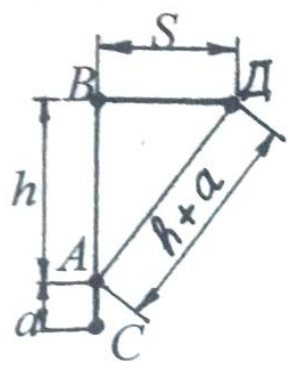

Рис. 2 - Схема до визначення величини зони затискання стебел у бральній секції: $\mathrm{h}$ - висота брання стебел - відстань від поверхні грунту до бральної секції; а - довжина, на яку потрібно витягнути стебло з грунту для повного обриву кореня, $\mathrm{a}=0,05 \mathrm{M}$

Для того, щоб стебло витягнути 3 грунту потрібно, щоб точка його затискання в бральній секції перемістилась в просторі на відстань $\mathrm{S}$ - на схемі рис. 2 з точки В у точку Д ( $\mathrm{S}=\mathrm{BД})$ таким чином, щоб АД $=\mathrm{BA}+\mathrm{AC}=\mathrm{h}+\mathrm{a}$. За теоремою Піфагора знаходимо: 


$$
\begin{aligned}
& \mathrm{S}=\mathrm{B} Д=\sqrt{\mathrm{AD}^{2}-\mathrm{BA}^{2}}=\sqrt{(\mathrm{BA}+\mathrm{AC})^{2}-\mathrm{BA}^{2}}= \\
& =\sqrt{2 \cdot \mathrm{BA} \cdot \mathrm{AC}+\mathrm{AC}^{2}}=\sqrt{2 \mathrm{~h} \cdot \mathrm{a}+\mathrm{a}^{2}}
\end{aligned}
$$

3 цієї формули видно, що чим більша висота брання $\mathrm{h}$ тим більшу відстань повинна пройти точка затиску стебла в просторі. Тому беремо висоту $\mathrm{h}$ не більшу 0,2 м - $\mathrm{h}=0,2$ м. Звідси $\mathrm{S}=\sqrt{2 \cdot 0,2 \cdot 0,05+0,05^{2}}=0,15 \mathrm{M}$.

Абсолютна швидкість переміщення точки затискання стебла, що витягується з грунту буде:

$$
\mathrm{v} \approx \sqrt{\mathrm{v}_{\mathrm{M}}^{2}+\left(\mathrm{v}_{\mathrm{r}}-\mathrm{v}_{\mathrm{p}}\right)^{2}}=\sqrt{2,2^{2}+(2,2-0,7)^{2}}=2,66 \mathrm{~m} / \mathrm{c} .
$$

Час за який стебло витягується 3 грунту складе: $\tau=\frac{\mathrm{S}}{\mathrm{v}}=\frac{0,15}{2,66}=0,056 \mathrm{c}$.

За цей час, затиснуте між роликом і пластиною стебло пройде відстань $\mathrm{S}_{\mathrm{p}}=\mathrm{v}_{\mathrm{p}} \cdot \tau=0,7 \cdot 0,056=0,039 \quad$ м. Тобто зона затискання стебел у бральному рівчаку повинна бути не менша 39 мм. Кут обхвату ролика притискною пластиною при цьому складе:

$$
\varphi_{\mathrm{p}}=\frac{180^{\circ} \cdot \mathrm{S}}{\pi \cdot \mathrm{R}}=\frac{180^{\circ} \cdot 39}{3,14 \cdot 21,5}=104^{\circ} .
$$

Висновоки. За встановлених параметрів компонувальна схема бральної ланки набуде наступного вигляду (рис. 3).

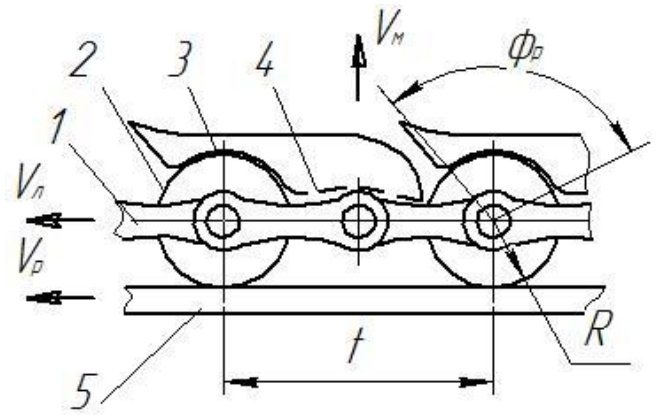

Рис. 3 - Компонувальна схема бральної ланки: 1 ланцюг; 2 - бральний ролик; 3 - притискна пластина; 4 підтримувач; 5 опорний транспортер

Встановлено: 1) швидкість переміщення бральних ланок (швидкість ланцюга) рівна $\mathrm{v}_{\text {л }}=2,2 \mathrm{M} / \mathrm{c} ; 2$ ) крок розміщення бральних ланок на ланцюзі $\mathrm{t}=86 \mathrm{mм}$; 3 ) радіус ролика $\mathrm{R}=21,5$ мм; 
4) колова швидкість ролика $v_{p}=0,7$ м/c; 5) зона затискання стебел у бральному рівчаку повинна бути не менша 39 мм, кут обхвату ролика притискною пластиною $\varphi_{\mathrm{p}}=104^{\circ}$.

3 врахуванням цього, можна виготовити макет ланцюгового брального апарату і досліджуючи його пересвідчитися в його роботоздатності.

\section{Література}

1. Пат. 75227 Україна, МКл A01D45/06. Ланцюговий льонобральний апарат./ С.Ф. Юхимчук, С.М. Юхимчук. .(Україна) Заявл. 15.05.2004. Опубл. 15.03.2006. Бюл. № 3.

2. Пат. 25414A Україна, МКл A01D45/06. Льонобральний апарат / С.Ф. Юхимчук, Г.А. Хайліс (Україна) - № 9505232; Заявл. 12.05.95; Опубл. 30.10.98, Бюл. № 4.

3. Пат. 22515A Україна, МКл A01D45/06. Машина для збирання льону / Хайліс Г.А., Божидарник В.В., Горбовий А.Ю., Юхимчук С.Ф., Довгополюк В.Ф., Дацюк Л.М., Клекоць Л.І., Ужегова О.А., Цикалюк Ю.О., Рудий С.М.(Україна) - № 97031357; Заявл. 25.03.97; Опубл. 17.03.98, Бюл. № 1.

4. Хайлис Г.А. Теория льноуборочных машин / Хайлис Г.А. - М.: Росинформагротех, 2011. - 322 с. 